\title{
The Fall of Arthur and The Legend of Sigurd and Gudrún: A Metrical Review of Three Modern English Alliterative Poems
}

\author{
Nelson Goering
}

\begin{abstract}
J.R.R. Tolkien produced a considerable body of poetry in which he used the traditional alliterative metre of Old Norse and Old English to write modern English verse. This paper reviews three of his longer narrative poems, published in The Legend of Sigurd and Gudrún and The Fall of Arthur, examining Tolkien's alliterative technique in comparison to medieval poetry and to the metrical theories of Eduard Sievers. In particular, the two poems in The Legend of Sigurd and Gudrún, which are adapted from Old Norse material, show a number of metrical and poetic features reminiscent of Tolkien's sources in the Poetic Edda. The Fall of Arthur, on the other hand, is in a style that is, in detail and in general, strongly reminiscent of Old English poetry. Throughout all these compositions, Tolkien employs a distinctive alliterative style, closely based on medieval and philological models, but adjusted according to the linguistic needs of modern English and to his own preferences.
\end{abstract}

The past five years have seen the publication of two significant works of long narrative poetry by J.R.R Tolkien, The Legend of Sigurd and Gudrún appearing in 2009, followed by The Fall of Arthur in 2013. ${ }^{1}$ There

1 My thanks go to Tom Shippey for his helpful comments on a draft of this review. 
are three major poems in these books (The Legend of Sigurd and Gudrún contains both the 'New Lay of the Volsungs' and the 'New Lay of Gudrún' as related but distinct works), all of which are written in a distinctive and nowadays unusual metre: a revival and adaptation of medieval Germanic alliterative verse. Together, these two books present a body of nearly 3000 lines of verse, representing a very considerable poetic effort on Tolkien's part. This piece reviews these works from a metrical perspective, in an attempt to sharpen our appreciation of how Tolkien reworked traditional alliterative verse to develop his own poetic technique.

The groundwork for studying Tolkien's alliterative style was laid by Tom Shippey in a 2009 essay in Lembas-extra (revised and reprinted in the 2013 collection Tolkien's Poetry). Shippey examined a sampling of Tolkien's alliterative writings from the 1920's to The Lord of the Rings, concluding that Tolkien went through a fairly steep learning curve before he gained a real mastery of the form. The Legend of Sigurd and Gudrún and The Fall of Arthur, neither of which were considered in detail by Shippey, seem to fall right in the middle of this period of development, and as such are of central importance for understanding Tolkien's career as an alliterative poet. The two books also form an excellent contrast with each other: the former draws on material from the Old Norse tradition, while the latter looks to Old English. The Norse and English varieties of alliterative verse were akin but by no means identical, and at least some of the differences are echoed in Tolkien's poetry. 
The first step in the metrical appreciation of verse is to get one's hands dirty: to pick apart the nuts and bolts of poetic form, to see what the poet did, or avoided doing, in the artful patterning of language. In the case of alliterative verse, which is based so closely on a medieval verse form, we cannot do this without taking into account the traditional rules and seeing where Tolkien followed or deviated from them. The latter cases can be as illuminating as the former. This technical approach will take up most of our attention in this review, but we should keep in mind throughout that this is all a necessary precursor to fully appreciating Tolkien's poetry as poetry. To reuse a well-known allegory, one must build a tower in order to glimpse the sea, and that requires piling a lot of stones.

\section{THE FALL OF ARTHUR}

Written in the early 1930's, the Fall of Arthur tells the first part of the story of Arthur's conflict with the usurper Mordred in 953 and a half lines of alliterative verse. In using this metre, Tolkien was picking up on a very venerable tradition in English poesie. The oldest recorded poem in English, Coedmon's Hymn, was composed in alliterative verse, and it was virtually the only metrical form used until after the Norman Conquest. The most famous works of Old English literature, from Beowulf to The Battle of Maldon, are alliterative compositions. 
Several centuries after the Norman Conquest, there was another flourishing of alliterative verse (now alongside rhyming verse), in what is usually called the Alliterative Revival of Middle English. It is debated what the connection of this Middle English verse form was to Old English poetry, ${ }^{2}$ but it is certainly a different metrical form, with distinct rules and stylistic preferences. However it may be, this 'revived' form itself eventually fell out of favour, its last recorded gasp the 16th century poem Scottish Field about the Battle of Flodden.

Although the narrative sources for the Fall of Arthur were mostly from Middle English-including the 'alliterative Morte Arthure', whose metre is indicated in its editorial title-Tolkien did not make use of Middle English verse forms for his foray into Arthurian legend. Instead, he turned to the classical form of alliterative verse from Old English, even though Arthurian legend is completely unknown in Anglo-Saxon literature. ${ }^{3}$

Our current knowledge of the rules of Old English alliterative metre is based on the work of 19th century philologists, who took an interest in old poems which

2 On the whole, I favour the arguments for a slow development, which only appears to us as a sharper break because of the poor attestation of alliterative poetry during the early Middle English period (Russom 2004, 297-9; Fulk 2004; Yakovlev 2008, esp. 282ff.). For a well-argued, but to my mind ultimately unconvincing, theory of how Middle English alliterative verse might have been effectively a new creation, see Cable (1991 ch. 2).

3 Tolkien's pairing of Middle English narrative content with Old English form is perhaps appropriate for a poem which imposes late medieval story and culture onto an early medieval stage. 
had been sidelined for centuries. The most influential of these researchers was the German Eduard Sievers, who published extensively on the workings of alliterative verse in the 1880's and 1890's. His magnum opus, the Altgermanische Metrik of 1893, remains influential to this day, and was highly regarded by Tolkien. Tolkien himself indeed wrote an insightful summary of Old English metrics in his preface to C.L. Wrenn's translation of Beowulf, reprinted more accessibly as Tolkien (1983), which is largely based on Sievers' work. ${ }^{4} \mathrm{He}$ also applied Sievers' system of scansion to his own alliterative compositions more than once, including to the Fall of Arthur (see the end of the Appendix, 232f.).

The structure of alliterative verse, as formulated by Sievers, is rather different from the poetic forms more favoured today. Metres like Shakespeare's iambic pentameter have a single rhythm, repeated line after line. By contrast, in alliterative poetry each line is made up of two units-known as half-lines or verses ${ }^{5}$-each of which has one of several distinct rhythmic patterns. The two half-lines are bound into a long line through alliteration, much as rhyme can

4 Tolkien's presentation is not an unmodified restatement of Sievers' principles, and contains some important insights on relative stress levels within lines, as acknowledged by Cable $(1974,71)$. It is also worth observing one of Tolkien's students, Alan Bliss, is the author of very well-known works on Old English metre (Bliss 1962a; Bliss 1962b), though I do not know to what extent Bliss' ideas were informed by those of his teacher.

5 This use of 'verse' therefore refers to a very small unit of poetry, not to a full stanza. 
make a pair of lines into a couplet (though this binding through alliteration is more fundamental and less variable than rhyme).

Tolkien employs this basic alliterative structure wholesale in the Fall of Arthur:

BELLS were SIlent, $\quad$ BLADES were RINGing (Arth V.24) ${ }^{6}$

The spacing in the middle marks out the two verses (half-lines). Each of these half-lines has two stressed syllables, here written in capitals, with the alliteration of ' $b$ ' linking the first stress in each half-line. This is the most basic form of an alliterative line: two stresses per half-line, the initial stresses in each alliterating with other.

There is an important difference between the first half-line and the second half-line in a pair. In the first, it is possible for both stresses to alliterate, as in this example:

FOES beFORE them FLAMES beHIND them (Arth I.61)

This is called double alliteration. It is prohibited in the second half-line, where the first stress (here 'flames') must alliterate, while second ('-hind') cannot and has to instead begin with some other sound. The nonalliterating final lift defines the line as a real poetic unit, and is a fundamental rule of Germanic alliteration.

6 Citations to the Fall of Arthur are by canto and line, and the poem itself is given the short title Arth for more economical reference. 
Slightly more elaborate patterns of alliteration are also possible, and we find Tolkien playing around with the possibilities in the Fall of Arthur. Take these lines:

\author{
FIERCEly HEARD she his FEET HASTen (Arth \\ II.111)

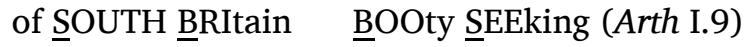

Here there are two alliterating sounds, and both stresses in both half-lines share in one or the other: line II.111 has the pattern $a b a b$ (F H F H), I.9 has the more unusual arrangement $b a a b$ (S B B S). The Fall of Arthur has an unusually high number of these 'crossed' alliterative patterns, ${ }^{7}$ which I found in over $7 \%{ }^{8}$ of the lines I scanned, nearly double rate of a classical Old English poem such as Beowulf. ${ }^{9}$

7 In more precise terminology, the second sort, $\mathrm{b}$ a a b, may be termed 'transverse' alliteration, though I will refer to both types indiscriminately as 'crossed'.

8 All of the statistics cited are from a scansion of part of the poem, specifically Cantos I, II, and the first 47 lines V (so not including the final 14 and a half lines of 'hasty' writing on separate paper). This amounts to 480 lines total, or slightly more than half the poem. Even if the full poem had been scanned, any figures should be taken with a large pinch of salt: the scansion of some lines is uncertain, and in any case there is always a danger that numbers can appear too definitive. As it is, all figures should be taken as provisional only.

9 Though the rate is lower than in the Fall of Arthur, Beowulf certainly does make use of crossed alliteration for artistic effect at key points, including in the very first line of the poem: hwat, wé GÁR-DEna in GEÁR-DAgum 'Lo, [we have heard of] the SpearDanes' [glory] in days of yore' (quoted from the 4th edition of Klaeber's Beowulf, with editorial marks adjusted in keeping with Tolkien's preferences). 


\section{THE FIVE RHYTHMIC TYPES}

In addition to the fundamental rules of alliteration, Tolkien also followed medieval practice in having every half-line belong to one of a set of permitted rhythmic types. As just mentioned, normal half-lines each have two stresses (in metrical terms these prominences are called lifts), but there is a great deal of flexibility in the arrangement of lifts and the less prominent material around them. Sievers identified five basic types, which he labelled A to E according to their frequency in Old English verse. Tolkien used all of these types in the Fall of Arthur, as the following examples show (in the abstract notation by each example, / indicates a lift, \ a partially stressed halflift, and $\mathrm{x}$ an unstressed dip; in the actual examples, SMALL CAPITALS stand for half-stress): ${ }^{10}$

10 These five + rhythmic types are widely used as a descriptive device in Germanic metrical studies, but there is considerable debate about just why these types should be permitted, while others are disallowed or strongly disfavoured. The best attempt to explain Sievers' system on internal principles comes from Nikolay Yakovlev in his 2008 DPhil thesis (ch. 1), closely building on the work of Thomas Cable (particularly his two books, The Meter and Melody of Beowulf from 1974, and The English Alliterative Tradition from 1991). Tolkien gave the somewhat vague explanation that the rhythmic types of Old English come from 'taking the half-dozen commonest and most compact phrase-patterns of the ordinary language that have two main elements or stresses' $(2013,227)$. A similar idea has been expanded into a fully fledged 'word-foot theory' of metre by Geoffrey Russom (see in particular Old English Meter and Linguistic Theory, 1987, and Beowulf and Old Germanic 


$\begin{array}{llll}\text { A } & / \mathrm{x} / \mathrm{x} & \text { BLADES were RINGing (Arth V.24b) } & 37.3 \% \\ \text { B } & \mathrm{x} / \mathrm{x} / & \text { from MARCH of ARMS (Arth I.23b) } & 30.5 \% \\ \text { C } & \mathrm{x} / / \mathrm{x} & \text { in ARMS PURposed (Arth I.1b) } & 26.2 \% \\ \text { Da } & / / \backslash \mathrm{x} & \text { HUGE HOAR-CRESTed (Arth II.4a) } & 0.7 \% \\ \text { Db } & / / \mathrm{x} \backslash & \text { SEA SIGHED beLOW (Arth II.24b) } & 1.2 \% \\ \text { E } & / \backslash \mathrm{x} / & \text { WAR HERE to WAKE (Arth I.30a) } & 4.1 \%\end{array}$

The final number in these examples gives the percentage of lines belonging to each type. As can be seen, for the first three types Tolkien's usage corresponds fairly well to medieval practice: type A is

Metre, 1998). Note that recent work has shown that some of the principles presented here as fundamental, such as the requirement for precisely two stresses per half-lines, are actually not basic: they are rather trends resulting from other, more core principles of metre. However, these are the insights of more recent, and in many ways ongoing research, and in the body of this essay I follow the more traditional presentation that Tolkien would have known and favoured.

I should mention that scholarly works on metrics, including those cited in this note, get into fairly deep technical waters. There is fortunately now an excellent and very readable guide to the metrical system by Jun Terasawa, which covers the basics as well as many more advanced topics (Old English Metre: An Introduction, 2011). Shorter introductions to the metrical system include Tolkien's own, already mentioned above, and the chapter on metre in Pope and Fulk (2001), a standard introductory edition of some shorter Old English poems. Those interested in the word-foot theory can find a basic introduction in Russom (2000), which includes a short analysis of Tolkien's alliterative verses from The Lord of the Rings (61ff.). A fuller introduction to the word-foot theory can be found in Bredehoft (2005). 
the most frequent, followed by B then C. However, Tolkien makes far greater use of type $\mathrm{E}$ than the two D types, while Old English poets went the other way around. Similarly, within type D Tolkien uses Db more often than $\mathrm{Da}$, again reversing the medieval norm. There is a good poetic-linguistic reason why Tolkien should have favoured types $\mathrm{Db}$ and $\mathrm{E}^{11}$ so much more than Old English poets. One of the characteristics of Old English poetry was a specialized vocabulary, which included a large number of compound words (and the ability to form new poetic compounds as needed). Type $\mathrm{Da}$ is perfect for holding such compounds-Tolkien's 'hoar-crested' is a fair example-but without them it is more difficult to get the needed build up of two stresses and a halfstress, / 八, all in succession. Modern English is much poorer in such compounds, and Tolkien prudently

${ }^{11}$ It is perhaps worth noting that some metricists, notably Thomas Cable, have argued that type $\mathrm{Db}$ really belongs with type E, not $\mathrm{Da}$ as Sievers' labelling would suggest (Cable 1974, 75-78). Cable's point is that the difference between a full lift and a half-lift is much less significant than the placement of the dip. Whether or not Cable is right about Old English, his comments seem to very appropriate to Tolkien's versecraft. Indeed, there are cases where it is difficult to tell whether a given verse is type $\mathrm{Db}$ or $\mathrm{E}$. Take for instance:

frail tongues of gold (Arth I.114b)

Which is the lift and which the half-lift, 'tongues' or 'gold'? Both are nouns, which tend to have relatively full stress, and alliteration gives us no clues. The stress seems to depend entirely on subtle and rather variable differences of emphasis. Cable's idea of a single $\mathrm{Db} / \mathrm{E}$ type sidesteps this problem, and suggests that the overall intonational contour of the verse is more important than the finer details of stress and half-stress. See further Yakovlev (2008, 74-77). 
refrained from trying too hard to reinstate this practice. On the other hand, types $\mathrm{Db}$ and $\mathrm{E}$ are much more accommodating of phrases, and Tolkien uses them for many three- and four-word groups that would be hard to fit in using the other types. The particular frequency of type E may be to its relatively ponderous quality: with its widely spaced main stresses, it tends to slow down the pace, adding rhythmic counterpoint to more frequent types. ${ }^{12}$ It may also sometimes be used for special emphasis, as in the example line I.30a, the first type $\mathrm{E}$ line in the poem, which foreshadows the strife that, despite Mordred's lying assurances, is destined to consume Britain.

\section{LIGHTER AND HEAVIER VERSES}

The five(-ish) types just laid out all have four 'metrical positions': two lifts, and either two dips or a half-lift and a dip. In the Fall of Arthur there are, occasionally, verses with a different number of metrical positions, such as the following:

A3 $\mathrm{x} \mathrm{x} / \mathrm{x} \quad$ then spake MORdred (Arth II.124a) $\quad 0.1 \%$

12 Megan E. Hartman has recently suggested that the late Old English poem The Battle of Brunanburh may have used ponderous versetypes in much the same way $(2014,85)$. 
This half-line has only one lift (indicated by both natural rhythm and alliteration), and corresponds well to a traditional type found regularly in Old English. Sievers regarded such verses as type A with a reduced or suppressed initial lift, and so gave them the fairly arcane label A3 (1885, 283f.). Type A3 verses have a fairly specific set of rules and tendencies: they always have at least four syllables, always appear in the first half-line of a pair, usually begin a section or passage, and often introduce travel, motion, or speech. This type is very rare in the Fall of Arthur, much more rare than in normal Old English use: in fact, the example here quoted is the only instance in my scanned sample of the poem (though there are others in the remaining cantos). It is notable that in this one use, Tolkien carefully follows all the traditional rules. Without knowledge of the medieval practice, this line might look like a mistake; as it is, it seems more like an effective use of the full range of options available in alliterative verse. The type's rarity might be at least in part due to Tolkien's fondness for vivid and forceful introductions to sections recounting journeys :

foes before them, flames behind them, ever east and onward eager rode they...

(Arth I.60-1)

With openings like these, Tolkien would have less use for the quieter upbeat of the A3 type.

Beyond this light type, Sievers identified certain heavier types with five metrical positions. The most important of these is a variant of type $\mathrm{D}$ with an extra dip having the rhythm / $\underline{x} / \backslash \mathrm{x}$ (the extra dip is underlined). Sievers labelled this type D*, using the 
star as his symbol for an added dip. Tolkien used this type very rarely, though there are a few clear examples, such as:

\section{Da* $^{*} \quad /(\mathrm{x}) / \backslash \mathrm{x} \quad$ COLD and KEENwingéd (Arth IV.116a)}

The interpretation of Tolkien's verses is not always straightforward, and there are a number of verses which could be, but are not necessarily, type $\mathrm{D}^{*}$ :

FEARless WANDering (Arth II.35b)

This verse could be scanned with -er- as a half-lift, making it type Da* as well. But if so, it would be a very odd example of such a type, which usually has double alliteration and stands in the first half-line in Old English. Moreover, if the -er really did serve as a half-lift then it would be strange that Tolkien avoided writing normal D verses of that sort, like:

\section{×WILD WANDERing}

The ${ }^{\mathrm{x}}$ marks this verse as one that is imaginable, but of a sort not actually used by Tolkien. Given this it might be better to scan II.35b and similar verses with poetic elision, fearless wand'ring, belonging to the common A type. This would explain the absence of half-lines like ${ }^{\mathrm{x}}$ wild wand'ring, since they would not belong to any acceptable rhythmic type.

The frequencies given above assume this sort of elision; if one prefers to scan them as type $\mathrm{Da}^{*}$ instead, then the total percentage of type $\mathrm{D}$ verses rises to about $1.4 \%$ in the sample. Even with this more generous scansion, type $\mathrm{D}^{*}$ verses are quite rare, 
which is of course in keeping with the infrequency of type $\mathrm{D}$ in general. ${ }^{13}$

\section{METRICAL LICENCES}

In addition to the five + rhythmic types, Sievers noted that Old English poets had several tricks at their disposal to accommodate more types of linguistic material into their poetry. Such metrical licences are important in narrative poetry, where there is constant tension between the demands of metre and the need to tell the story one has in mind, and Tolkien found them no less useful than his Old English predecessors.

\section{EXPANDED DIPS}

Although the most basic form of each of Sievers' rhythmic types has four syllables, this is just a minimum. In general, a group of unstressed syllables can stand in the same position as a single one without making a difference to the rhythmic type of the half-

13 The expanded type remains rare throughout most of Tolkien's alliterative corpus. There seem to be none, for instance, in the late poem For W.H.A., written for W.H. Auden in the late 1960's. Carl Phelpstead did scan one line, fashions verses with art, as $\mathrm{Db}^{*}$ giving it the rhythmic pattern / x / x x \(2013, 54), but 'fashions' begins with a short syllable ('sh' representing a single consonant despite being written with two letters) and should most likely be resolved as a single lift (see below), giving it the more normal Db pattern / / $\mathrm{x}(\mathrm{x}) \backslash$. 
line. This means that the following half-lines all count as 'the same', type A, in scansion:
$/ \mathrm{x} / \mathrm{x}$
BLADES were RINGing (Arth V.24b)
$/ \mathrm{x}(\mathrm{x}) / \mathrm{x}$
MORdred was MARCHing (Arth II.99a)
$/ \mathrm{x}(\mathrm{x})(\mathrm{x}) / \mathrm{x}$
FAITHful hast thou FOUND me (Arth I.29a)

All three of these half-lines have the same structure of lifts and dips, but vary in the number of syllables in the first dip. There are some important limitations on this licence. It is generally only used to work in an extra syllable or two, though more are certainly possible (especially in types $\mathrm{B}$ and $\mathrm{C}$ ). More importantly, only syllables in the first dip of a halfline can be expanded-later dips are generally limited to just one syllable.

Although expansion may have some limitations, it is extremely common. Two of the types, B and C, begin with a dip, and these are expanded more frequently than not-this is true equally in Beowulf and the Fall of Arthur (see Bliss (1962a, sec. 57, 60) for the numbers in Beowulf). The following are very typical examples of $B$ and $C$ verses with expanded dips:
B $\mathrm{x}(\mathrm{x}) / \mathrm{x} /$ from the WEST comes WAR (Arth I.105a)
C $\mathrm{x}(\mathrm{x}) / / \mathrm{x}$ that no WIND DAUNTeth (Arth I.105b)

By contrast, type A verses do allow expansion, but the basic four syllable type is more usual. This greater 
preference for expansion in types $\mathrm{B}$ and $\mathrm{C}$ as compared to type A is, again, as true of Beowulf as the Fall of Arthur, and suggests an interesting similarity of practice even on a relatively fine level of detail (perhaps due in part to interactions of verse type and linguistic material which are as alive today as in Old English).

\section{ANACRUSIS}

One of the patterns that English, whether Old or modern, most naturally falls into is an alternation of non-stress and stress: $\mathrm{x} / \mathrm{x} / \mathrm{x}$. This pattern is conspicuously rare in ancient alliterative verse. Old English poets generally avoided this rhythm, though they could, in need, tack on an extra very light syllable or two at the start of a type A or D half-line: this embellishment is known as anacrusis. Such a rhythm is even harder to avoid in modern English, with its articles and mandatory prepositions, and Tolkien understandably uses anacrusis relatively frequently in the Fall of Arthur (in over $8 \%$ of the lines I scanned):

$$
\mathrm{A}+\quad(\mathrm{x}) / \mathrm{x} / \mathrm{x} \quad \text { the death and darkness (Arth V.31a) }
$$

The article 'the' is easily glossed over and does not 'count' in determining the rhythmic type-so this is a type A line with an anacrustic syllable in front. Since anacrusis is a fairly major licence, with potential to obscure the rhythmic type of a half-line, Old English poets tended to be fairly restrained in their use of it. If 
a half-line had anacrusis, it would usually also have double alliteration (and therefore usually appear in the first half-line of a pair, since double alliteration was not permitted in second half-lines).

Tolkien followed these tendencies, but less strictly than most Old English versifiers. He occasionally put an anacrusis in a second half-line, but $98.7 \%$ of his anacruses in Arthur are in first half-lines. Of these, many have double alliteration (as in the example above) or else make use of crossed alliteration:

on SHORES UnGUARDed SHIELDS are GLEAMing (Arth I.158)

In Tolkien's versecraft, crossed alliteration seems to stand in as the equivalent of double alliteration. But even so, a full quarter of Tolkien's anacruses have only plain single alliteration, such as:

for HEART misGAVE her (Arth II.121)

This is a significant and remarkable deviation from the practice of Old English poets. There are occasional similar verses, such as this line from The Battle of Maldon (a poem known for its relatively looser metrical form):

he LÉT him pá of HANDon LÉOFne FLÉOgan $(\text { Mald 7) })^{14}$

'then he let from his hands his dear [hawk] fly'

14 Cited from Dobbie (1942). 
The rhythmic pattern of the first half-line is ( $\mathrm{x}) / \mathrm{x}(\mathrm{x})$ (x) / $\mathrm{x}$, a heavily expanded type A line with anacrusis. But Maldon is not typical of Old English poetic practice generally, and in any case the chief peculiarity of this poem is to show more anacruses in second half-lines. Tolkien's precise habit of restricting anacrusis to the first half-line, but allowing more flexibility with the alliteration, is unparalleled in Old English verse. Just why he allowed himself more freedom in this regard is not immediately obvious. One possibility is that he was giving his poem a touch of Middle English flavour, since the later Middle English style of alliterative verse freely permitted such 'anacruses.' ${ }^{15}$ However, comparison with Tolkien's other alliterative poems shows this to be unlikely. The Lay of the Völsungs shows precisely comparable rates of single alliteration in verses with anacrusis, and the Lay of Gudrún is even looser in allowing anacrusis to occur without double alliteration. In the alliterative verses recited by Théoden, Éomer, and the anonymous composer of the 'Mounds of Mundburg' in The Lord of the Rings, fully

15 Though properly speaking, in the later tradition such upbeats were not anacrustic extra syllables, but normal parts of the core rhythms. It is also worth emphasizing that Middle English verse has its own rules, and many of Tolkien's anacrustic verses, such as Arth I.158a and II.121a, would actually be marginal, if not outright unmetrical, in poems like Sir Gawain and the Green Knight (Yakovlev 2008, 156ff.). Although the formal understanding of Middle English metrics is far advanced from its state in Tolkien's day, I would expect that, if he had meant to invoke the rhythms of the Alliterative Revival, Tolkien would have possessed the rhythmic intuition to do so more effectively. 
half of the verses with anacrusis lack double alliteration, as in:
$(\mathrm{x}) / \mathrm{x}(\mathrm{x}) / \mathrm{x}$
as WIND in the MORning (Mund 4a)

The divorce of anacrusis and double alliteration look like a core part of Tolkien's alliterative style, apparently a concession to the rhythms of modern English.

Beyond giving himself more alliterative freedom, Tolkien also allowed himself to use anacrusis with the rhythmic type E, although Old English poems had avoided employing the licence here to reduce confusion in this rare metrical type. However, type E was nowhere near so rare for Tolkien as for the AngloSaxons, and even if he were not freer with anacrusis more generally, it would not be surprising that he would feel more comfortable using it with this rhythmic pattern.

\section{RESOLUTION}

In contrast to the two metrical licences just discussed, the process traditionally known as resolution concerns the stressed syllables in lifts. Normally, a lift must be filled by a long stressed syllable. All stressed monosyllables count as long. In polysyllabic words, a stressed syllable is long if it either contains a long vowel, or else if it is followed by a consonant cluster. Any stressed syllable that does not meet these conditions (i.e. has a short vowel, is in a polysyllabic 
word, and is followed by a single consonant) counts as 'short', and is generally too light to form a lift on its own. Such syllables must be 'resolved' with the following syllable so that the two syllables together constitute a single metrical position:

from the FOREST'S MARgin (Arth I.203b)

The 'fo-' of forest's is short, and therefore resolves so that the whole word 'forest's' stands as a single lift. This half-line is properly scanned as having the type $C$ rhythm $\mathrm{x}(\mathrm{x}) / / \mathrm{x}$, and not (as one might be tempted at first glance, without knowing about resolution) $\mathrm{x} x / \mathrm{x} / \mathrm{x}$. Tolkien himself confirms the rhythm of this particular line in his scansion included in the Appendix to The Fall of Arthur.

In using resolution, Tolkien was carefully adhering to a distinction between 'long' and 'short' syllables which has become rather unintuitive in modern English (largely due to linguistic changes in the Middle English period). ${ }^{16}$ These rules, including the distinction between long and short vowels, were perfectly natural to Old English speakers and poets, and formed an organic part of the language (and therefore of the poetry). These rules are also very familiar to modern philologists: Tolkien was not trying to make things

16 The difference between long and short syllables was still fully active earlier Middle English. Tolkien's discovery of the regular distinction between two verbal types in the AB language, presented in his 1929 essay Ancrene Wisse and Hali Meiðhad, rests on syllable length: the fondin-class consists of words with long first syllables, and the polien-class of those with short (Tolkien 1929, 118-24). 
easy for a general modern audience, but rather, it seems, writing first and foremost for himself, and for people who might share his particular tastes and interests.

Resolution is, it should be said, not actually a metrical licence as such. In the example just given, there is no choice but to resolve 'forest' into a single lift. Furthermore, there are lines where resolution has to be 'suspended', such as:

lay the VEILED FORest (Arth 71b)

Here we have a type C verse, $\mathrm{x}(\mathrm{x}) / / \mathrm{x}$, seemingly violating our rule of resolution. But this is entirely regular: when immediately following another lift, resolution normally does not occur, and each syllable counts on its own as one of the four metrical positions of the verse. ${ }^{17}$ Resolution is surely one of the hardest aspects of alliterative verse for a modern reader of Tolkien's poetry to get to grips with, especially one without any background in a language with length distinctions like Old English (in this regard, Latin, Greek, or Sanskrit would do just as well). But while it is critical for properly figuring out the pattern of metrical positions in each verse, it is perhaps less

17 The situation in Old English, especially in Beowulf, is considerably more complicated, and governed by the controversial principle known as Kaluza's law. Those who wish to know more may consult Neidorf and Pascual (2014), who provide a relatively accessible and up-to-date discussion of the law, and have ample references to earlier literature. My DPhil thesis will also contain a chapter on the law, and on resolution in Beowulf more generally. 
illuminating about his alliterative practices since he adheres to the medieval rules so thoroughly.

\section{ARRANGEMENT AND STYLE}

Just as with the nuts and bolts of rhythm and alliteration, we see that in style and structure Tolkien draws heavily on Old English tradition, while also making his own innovations and creating his own version of narrative alliterative verse. Innovation is most obvious in his division of the poem into cantos of roughly 220 lines apiece (the fifth is a mere 63 and a half, but only because the poem breaks off at that point). No Old English poem is arranged into units of comparable size and coherence. Beowulf does show a division into 43 fits, but these are all shorter and have nothing like the narrative unity of the cantos in Tolkien's poem.

However, on a smaller scale Tolkien's practices resemble those of Old English much more closely. Within each canto, although lines do group loosely into 'paragraphs' of sorts (marked by a skipped line), there is no formal stanzaic structure and the poem essentially runs on continuously. This is known as a stichic style, and is a characteristic trait of Old English verse.

More distinctively, transitions from one thought to another often take place not at the end of a line, but over the break between two half-lines in a pair. A simple example can be cited from canto I, just after Arthur has heard of Mordred's betrayal: 
Swift then sent he to summon Gawain bold in counsel. Bitter words he spake; the evil tidings all he told him.

(Arth I.181-183)

A full stop, marking the transition from the summons to the actual conversation, falls in the middle of line 182. 182a finishes the description of Gawain from 181, while $182 \mathrm{~b}$ begins a new thought, which is expanded on in 183. This sort of staggering of syntax and thought across lines is known as enjambment (German metricists have labelled the specifically Germanic practice of placing syntactic boundaries at half-line breaks Hakenstil, 'hook-style'), and it was a beloved device of Old English poets.

Much more could certainly be said of the specific poetic devices in the Fall of Arthur. One might make special mention of the particularly finely rendered battle scene of canto IV, with its effective shifts from the impersonal and general to the specific and detailed. And although The Fall of Arthur was not yet published when Shippey wrote his foundational essay on Tolkien's alliterative verse, a good deal of what he has to say applies to this poem. A more focused examination of the poem from this perspective would no doubt reveal much more.

\section{SUMMARY}

The Fall of Arthur follows most the basic rules of Old English alliterative verse, from the fundamental arrangement of half-lines and alliteration to metrical licences such as anacrusis. There are points of 
difference, such as the increased frequency of the historically rare type $\mathrm{E}$ or the freer employment of anacrusis, which by and large seem to be the result of accommodating the verse-form to the different linguistic realities of modern English. Other features, such as the high prevalence of crossed alliteration, seem to reflect Tolkien's artistic choices in this poem, and show a degree of individuality in the process of taking a traditional form and applying it to a new creative purpose.

\section{VÖLSUNGAKVIĐA EN NÝJA}

The Legend of Sigurd and Gudrún contains two long narrative poems in alliterative verse, which together relate a large body of legend covering the exploits and feuds of two heroic families, the Völsungs and the Nibelungs (or Niflungs, to give them their name in Norse form). Their relationships to various medieval narratives have been covered well, both in Christopher Tolkien's commentaries in the book itself and in Shippey's excellent review article from 2010, but the details of the metre have not been closely examined. Unlike the majority of Tolkien's alliterative poetry, these two works are firmly oriented towards the old Norse literary tradition, in particular the poems of the Poetic (or Elder) Edda, raising some interesting questions about the metre: to what extent did Tolkien emulate the distinctive features of Norse verse, and how much do his practices differ from his other alliterative writings? Since the answers to these 
questions are not quite the same for the two poems in the book, I will consider them one at a time.

The first poem in The Legend of Sigurd and Gudrún, in full titled the 'Völsungakviða en nýja eða Sigurðarkviða en mesta' (that is, 'The New Lay of the Völsungs or the Greatest [or Longest] Lay of Sigurd'), covers many of the more 'mythological' parts of the tale. Beginning with the family history of the descendants of Völsung, ${ }^{18}$ its main theme is the life of the great hero Sigurd: his dragon-slaying, romance with the Valkyrie Brynhild, and disastrous encounter with the Nibelungs.

Tolkien drew on several medieval sources for this legend, but, as the titles and names make clear, he looked first and foremost to the heroic poems of Poetic Edda preserved in the Codex Regius (GKS $23654^{\text {to }}$, now held by the Árni Magnússon Institute in Iceland). From a metrical perspective, the most obvious feature of this poetic collection is that not all the Norse poems in this cycle are written in the same metre: in contrast to the single type of Old English alliterative verse, there are three different Eddaic metres, which vary in terms of their alliterative rules and the patterning of rhythmic types. Of these metres, the one most relevant to the Völsungakviða is known as fornyrðislag, the 'metre of old tales'. This is the most similar of the three to the single Old English alliterative metre (though there are a number of differences in detail), and was used for the bulk of the nine Eddaic poems

18 A story of death, incest, and werewolves, one wonders why this has not yet been made into a popular TV series. 
which supply most of the material for the Völsungakviða. ${ }^{19}$ Unless otherwise qualified, any references to 'Old Norse metre' in this part of the review are to fornyrðislag.

\section{VERSES AND RHYTHMS}

As expected from the similarity between fornyrðislag and Old English metre, the basic structure of alliterating half-lines in the Völsungakviða is essentially the same as in the Fall of Arthur. This is, however, slightly obscured on the page by different editorial conventions. Instead of printing pairs of verses as long lines, editors of Old Norse poetry often present each half-line individually as a 'line.' ${ }^{20}$ Tolkien follows this convention, although it is entirely a modern editorial choice rather than a substantive difference between English and Norse. (Medieval scribes, whether Norse or English, simply wrote their text out continuously, since parchment space was far too valuable to be wasted by putting as little text per

19 This is counting the heroic poems from Grípisspá to Helreið Brynhildar, as well as Voluspá, which provides some content for Tolkien's 'Upphaf'. In this set of poems, there are around 2186 halflines of fornyrðislag and 512 verses in the ljóðaháttr metre (numbers taken from Seiichi Suzuki's The Meters of Old Norse Eddic Poetry).

20 The late Ursula Dronke, one of Tolkien's students, adopts this approach in her (unfortunately only partial) edition (Dronke 19692011). It should be noted that one of the most important editions of Eddaic poetry current in Tolkien's day, Gustav Neckel's from 1914, adopts a lineation more like that standard for Old English and prints half-lines in pairs. 
page as in a modern edition of poetry.) Thus in Sigurd and Gudrún we find lines printed like this:

As the wolf I walk

wild and lonely

(Vol V.30.5-6) $)^{21}$

This could just as well have been reprinted in the style of the Fall of Arthur as:

As the wolf I walk wild and lonely

This has no metrical significance, but the choice of Norse editorial style is an easy way for Tolkien to signal the affiliations of his poem.

The verses themselves show the same set of rhythmic types as the Fall of Arthur, which were anciently shared by both English tradition and Norse fornyrðislag: ${ }^{22}$
A $\quad / \mathrm{x} / \mathrm{x} \quad$ HANDS of HEALing (Völ VI.6.1)
$37.2 \%$
B $\quad \mathrm{x} / \mathrm{x} /$ the BLAZing BRIDGE (Völ U.11.3
$32.5 \%$
C $\quad \mathrm{x} / / \mathrm{x}$
my BLOOD-BROTHer (Völ IX.24.3)
$23.5 \%$
Da $/ / \backslash \mathrm{x}$
HARD, HANDLINKéd (Völ III.3.5)
$0.5 \%$
Db $/ / \mathrm{x} \backslash$
WISE WORDS he SPAKE (Völ V.2.7)
$2.6 \%$
$\mathrm{E} / \backslash \mathrm{x} /$
WILD BLEW the WIND (Völ II.20.5)
$3.7 \%$

${ }^{21}$ I cite the Völsungakviða (Völ) by section, stanza, and line number. The first section, 'Upphaf', has no section number, and is cited as ' $U$ '. There is no need to use ' $a$ ' and ' $b$ ' to distinguish first and second half-lines in a pair, since odd numbered half-lines will always be first, even second.

22 The percentages are based on a sample consisting of the 'Upphaf' and section V, 'Regin', amounting to 264 long lines (528 verses). 
In terms of the overall proportions of verse-types used, Tolkien does not seem to have done much to emulate some of the peculiarities of the Norse tradition. In the Edda, rhythmic type B is actually rather uncommon, much less frequent than type $C$ (Sievers' lettering reflects Old English frequencies, not Norse). Type Db is also extremely rare in Norse, even rarer than in Old English, but Tolkien maintains a preference for this pattern over type Da.

Indeed, on the whole Tolkien's choice of rhythmic types is strikingly similar to his practice in the Fall of Arthur, both in the relative frequency of types (e.g. preference for type $\mathrm{E}$ and $\mathrm{Db}$ over $\mathrm{Da}$ ), and in the specific proportions. The relative numbers hold true of a great many of Tolkien's alliterative poems, ${ }^{23}$ but these two poems agree unusually precisely in the absolute percentages of the different rhythmic types. This close similarity (based on, I must emphasize again, but a sample of each poem) may imply that both the Völsungakviða and the Fall of Arthur were written around the same time, at more or less the same point in Tolkien's development as an alliterative writer. This would fit well with Christopher Tolkien's guess that his father turned to the Norse material after abandoning the Lay of Leithian in 1931.

The correspondence in types extends to the rarity of heavy D* verses, though there are a couple of clear examples:

23 The verses of the Rohirrim in The Lord of the Rings and the much later praise poem For W.H.A. both share the same relative frequency of types (see Phelpstead $(2013,53)$ for the breakdown of types in the latter poem). 


\section{Da* $\quad /(\mathrm{x}) / \backslash \mathrm{x} \quad$ ALL must ANdvari (Völ V.11.1)}

Some verses which apparently belong to this type are particularly strange from a Germanic perspective:

\section{Da* $^{*}+\quad(\mathrm{x}) /(\mathrm{x}) / \backslash \mathrm{x} \quad$ the FALLS of ANDVAri (Völ V.7.1)}

This looks like an extremely complex verse, a heavy D* type with anacrusis, and such a verse would normally show double alliteration in the medieval traditions. This verse is not a mere slip on Tolkien's part, since 'the $\mathrm{X}$ of Andvari' is a formula which Tolkien repeats elsewhere in this poem and in the Guðrúnarkviða, never with double alliteration. Tolkien's flexibility here may be the result of the conflicting demands of modern English, with its unstressed syllables, and of Norse names like Andvari which, if in a closely bound phrase with another noun, fit best into types $\mathrm{D}$ or $\mathrm{E}$.

As in the Fall of Arthur, we also find the occasional light type A3 verse, but the type is extremely rare:

\section{A3 x x / x long ruled SIGmund (Völ III.2.1) $\quad 0.4 \%$}

The Völsungakviða does diverge very significantly from the Fall of Arthur in allowing the occasional half-line with just three syllables:

\section{A- / x / Sigmund's son (Völ V.18.5) $\quad 0.4 \%$}

Here Tolkien is echoing a real difference between English and Norse poetry, since the latter alone could 
allow three syllable verses. Their inclusion helps lend a distinctively Norse air to the Lay of the Völsungs, which in its set of types otherwise is indistinguishable from the Fall of Arthur.

\section{SYLLABLES AND THE BREVITY OF NORSE}

Tolkien also makes the Völsungakviða more like his Norse sources by keeping the overall syllable count of verses low. Like Old English, Norse poetry could work in extra unstressed syllables by expanding dips, and Tolkien certainly uses this licence in his Norse poetry:

$$
\begin{array}{ll}
/ \mathrm{x} / \mathrm{x} & \text { HANDS of HEALing (Völ VI.6.1) } \\
/ \mathrm{x}(\mathrm{x}) / \mathrm{x} & \text { BIRDS in the BRANches (Völ V.49.5) }
\end{array}
$$

However, Tolkien employs this licence with more restraint in the Völsungakviða. I have not been able to find a clear example of type A with three unstressed syllables in the first dip. ${ }^{24}$ This restraint creates a stark contrast between the Völsungakviða and the Fall of Arthur in syllable counts, which I show on the table below. For each poem, it gives the percentage of verses that have a given number of syllables, ranging

${ }^{24}$ V.37.1 Far enow thou fleddest may be a candidate, if 'far' as actually meant to be stressed. Otherwise, the line is type A3. 
from light three syllable half-lines to the longest attested with seven: ${ }^{25}$

$\begin{array}{llllll}\text { Syllables: } & \underline{3} & \underline{4} & \underline{5} & \underline{6} & \underline{7} \\ \text { Völ: } & 0.4 \% & 72.5 \% & 25.3 \% & 1.6 \% & 0.2 \% \\ \text { Arth: } & 0 \% & 57.7 \% & 36.5 \% & 5.6 \% & 0.2 \%\end{array}$

In the Völsungakviða, nearly three quarters of all verses have four syllables or fewer, while this is true of rather less than two-thirds of the half-lines in the Fall of Arthur. These numbers confirm our impression that Tolkien's Norse poem is much the terser, just as Old Norse poetry is when compared to Old English.

However, it is extraordinarily difficult to truly mirror the brevity of Old Norse in modern English, and Tolkien allowed himself some extra flexibility in his use of unstressed syllables. This can be illustrated by the variety of type $B$ verses used by Tolkien. In general, dips are less expandable towards the end of a verse: the last dip in types $\mathrm{A}$ and $\mathrm{C}(/ \mathrm{x} / \mathrm{x}$ and $\mathrm{x} / / \mathrm{x})$ are verse-final and cannot be expanded at all in either tradition. In type $\mathrm{B}(\mathrm{x} / \mathrm{x} /)$ the second dip could be expanded in Old English-but only by one syllable. So

${ }^{25}$ These numbers count resolved sequences as a single syllable, since resolution does not increase the total 'weight' of a verse. If we ignore resolution, the syllable counts are somewhat higher all around, but the relative frequencies are similar. Old Norse rules for resolution were somewhat different from Old English, but Tolkien seems to have followed the English rules throughout his alliterative verse. 
half-lines like the following were perfectly acceptable in Old English verse:

$\mathrm{x}(\mathrm{x}) / \mathrm{x}(\mathrm{x}) /$ from the MOUTHS of the RHINE (Arth 43a)

Old Norse favoured brevity, and did not allow this; only the first dip could have more than one syllable, while the second was strictly limited to a single syllable. Tolkien, however, not only ignored this limitation, but occasionally included verses expanded even further:

$\mathrm{x}(\mathrm{x}) / \mathrm{x}(\mathrm{x})(\mathrm{x}) /$ from the MARGin of the WORLD (Völ U.9.8)

This trisyllabic second dip would not even have been allowed under Old English rules, and is far fuller than fornyrðislag would normally tolerate. Tolkien employs this expansion very sparingly, at least in the Völsungakviða and the Fall of Arthur (which have one example each in the scanned portions), but it is clearly a part of his metrical practice.

Tolkien also deviates strikingly from Norse tradition by allowing anacrusis in the Lay of the Völsungs. His use of this device is much like in the Fall of Arthur, though in this poem he uses it slightly less frequently, ${ }^{26}$ and crossed alliteration is somewhat rarer in general. What is interesting is that he employs this licence at all, since anacrusis was strictly forbidden in fornyrðislag. Anacrusis, it seems, was a device Tolkien simply could not do without, being too useful for

${ }^{26}$ In $6.4 \%$ of verses as compared to $8.2 \%$. 
working in the unstressed initial syllables so common in modern English phrases.

\section{ALLITERATION}

There is not much that needs to be said about alliteration, since it by and large works as in the Fall of Arthur, but a few points should be noted. Firstly, crossed alliteration is less common than in Tolkien's Arthurian poem, more closely resembling the typical rates of medieval poems. Secondly, the Völsungakviða provides a particularly fine example of alliteration as a guide to the proper reading of a passage. When Sigmund is asked by his rival Siggeir to sell him Ódin's sword, he refuses:

\footnotetext{
To my hand made, for me destined, I sell no sword to Siggeir ever. (Völ II.16.5-8)
}

The alliteration of the first pair of verses is on ' $\mathrm{m}$ ', and 'my' and 'me' stand in the most prominent lifts of the line: it seems clear that we should read this as an emphatic statement by Sigmund as he claims ownership of the sword: "to my hand made, for me destined'.

On a similar note, Tom Shippey pointed out in his review of Sigurd and Gudrún that Tolkien breaks the most regular rule of alliteration, that the final lift in a pair of half-lines should not alliterate, at one point in 
the poem (Shippey 2010, 318). When the effects of the potion of forgetfulness are lifted, Sigurd suddenly comprehends the situation he has ended up in:

oaths were remembered all unfulfilled.

(Völ IX.4.3-4)

The scansion of the second of these half-lines is somewhat difficult, and Shippey hesitates before concluding that the second lift of the second half-line is filled by un-. Since all vowels alliterate with all other vowels, this gives the verse double alliteration, and this faltering of the alliterative pattern, echoing the broken oaths, ushers in the tragic final act of the poem. I agree with Shippey on both counts: that the line is hard to scan, but that the most plausible scansion is to stress un-, with artfully employed 'incorrect' double alliteration. ${ }^{27}$

Finally, Tolkien departed from his Norse models in a relatively minor but telling way by having a fairly high rate of double alliteration in types $\mathrm{B}$ and $\mathrm{C}$ : among those in the first half-line (the only ones eligible), the rates are $68.3 \%$ and $55.1 \%$ respectively, compared to about $19.2 \%$ for B and $25 \%$ for C in the Edda (Norse data from Suzuki $(2014,86,91 f)$.$) . The$ rates in Norse are fairly low for slightly different reasons in the two types. In type $\mathrm{C}$, the medieval poets preferred to fill the last three metrical positions with a

27 Having a lift filled by a negative prefix would certainly be allowed under medieval practice. 
single trisyllabic word, as in this typical example from the first Guðrúnarkviða:

fyr Guðrúno

'before Gudrún'

$(G \partial r I 3.4)^{28}$

This sort of thing was very easy in Norse, where case endings often provided the needed third syllable. In modern English, this structure is harder to come by, since although trisyllabic words are common, not many have the right stress pattern for a type $C$ verse. On the occasions Tolkien does use this typical Eddaic structure, it is more often than not in phrases containing a Norse word or name, like:

as Valkyrie (Völ V.54.4) ${ }^{29}$

Since Tolkien so often filled the two lifts with different words, he had considerably more scope to work in double alliteration.

Type B, much less frequent in Norse, was more often made with a phrase rather than a single word, but double alliteration was even rarer. In general, the

28 Cited from Neckel (1914).

29 The stress pattern here is, properly speaking, $\mathrm{x} / \backslash \mathrm{x}$ rather than $\mathrm{x} /$ / x. Many modern metricists, including both Cable and Russom, would see this half-stress pattern as actually more basic to type C, and the more strongly clashing double stress of $\mathrm{x} / / \mathrm{x}$ as a less common variant (though hardly a rare one). However this may be for the medieval poetry, Tolkien clearly preferred the more strongly clashing type, and only occasionally, as in V.54.4, works in a falling type $\mathrm{C}$ verse. 
second lift of such phrases often seems significantly subordinated to the first, almost more like a half-lift than a full one:

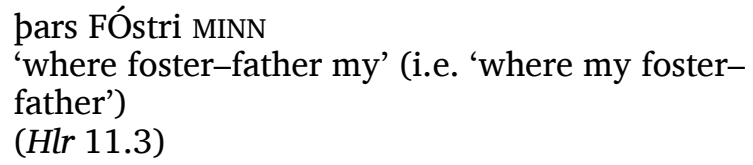

In this typical example, from Helreið Brynhildar, the second lift is filled entirely by a possessive pronoun, the sort of word usually of weaker stress and less prone to alliterate. Verbs, another type of word often used in the second lift of type B verses, also occupied an intermediate stress category in the old Germanic languages. These would seem to favour a scansion of many type $\mathrm{B}$ verses as $\mathrm{x} / \mathrm{x} \backslash$ rather than $\mathrm{x} / \mathrm{x} /$ (Russom 1998, 20, 23). Modern English probably would have allowed Tolkien to emulate this rhythm, but he preferred to use more strongly stressed words for both lifts and to work in a great deal of double alliteration. It may be that, because he was using a poetic form unfamiliar to most today, he wished to emphasize the rhythmic structure of the verses as much as possible.

\section{THE LJÓĐAHÁTTR STANZAS}

As Christopher Tolkien observes in his commentary, three stanzas in the Völsungakviða are not in the same fornyrðislag-like metre as the rest. In the fifth section of the work, Sigurd roasts the recently slain dragon's 
heart while his companion, the dwarf Regin, sleeps. When Sigurd tastes the juice of the heart, he gains understanding of the speech of birds, and we get three stanzas (V.42-44) of bird-speech warning Sigurd that Regin will try to kill him.

These stanzas each have six verses, instead of the normal eight, and it is clear that they do not follow the usual rules we have observed so far. To take the third stanza as an example:
'A head shorter
should hiding dwarf
deprived of gold perish!
There Regin rouses
in rustling heather;
Vengeance he vows for brother.'
(Völ V.44)

This type of sequence is very unlike the fornyroislag style verses familiar from the rest of the poem, instead corresponding to another Old Norse Eddaic metre known as ljóðaháttr, the 'style of songs'. Each stanza is divided into two half-stanzas. Each half-stanza starts with a normal pair of alliterating half-lines, more or less corresponding well to normal fornyrðislag verses, followed by a heavier third verse with two or three lifts and internal alliteration. This third line, often called a full line, can have a variety of rhythms, but very often ends with a pair of resolved syllables or, somewhat less often, a heavy monosyllable. Tolkien holds to this traditional tendency, usually using a resolved sequence (as both 'perish' and 'brother' are in this stanza) and once using a heavy monosyllable ('hell'); on the phrase 'won it' in V.43.6 really deviates 
from normal medieval practice (for a concise overview of the ljóðaháttr, see Árnason (1991, sec. 2.4)).

In the Edda, ljóðaháttr is regularly used for magical charms and wisdom poetry, and often for dialogue, all of which seems well-suited to this supernatural interlude of bird-speech (see in general Heusler (1925, sec. 315)). There is also a similar shift in metre in Tolkien's source for this episode, the Fáfnismál, though Tolkien's use of the Eddaic poem is not entirely straightforward. The majority of this poem, which relates Sigurd's conversation first with the dying dragon and then with Regin, is in ljóðaháttr, before it switches to fornyrðislag in the $32^{\text {nd }}$ stanza, at the point the birds begin to speak. The next few stanzas vary between the two metres (of the seven stanzas of birdspeech in the original, four are in fornyrdislag and three in ljóðaháttr). Christopher Tolkien notes that his father thought that only the three ljóðaháttr verses were original (Tolkien 2009, 211-13), and they do provide most of the content for the bird-stanzas in the Völsungakviða (though Tolkien is not closely translating the original here). By setting aside the fornyrðislag stanzas as an interpolation, Tolkien viewed the enitre original poem as exclusively in ljóðaháttr, with no metrical alternations. Tolkien thus draws on a hypothesized original Fáfnismál for his content, but by shifting metre at this point in the Völsungakviða he is mirroring the manuscript as we have it. 


\section{STRUCTURE AND STYLE}

Much as the Fall of Arthur incorporates many key stylistic features of Old English poetry, Tolkien worked important elements of Norse versecraft into the Völsungakviða. The most obvious of these is the arrangement of half-lines into stanzas, which is very unlike the continuous flow of lines in Old English. Like the Old Norse poems Tolkien was following, the typical stanza has eight half-lines, usually with a pause or break of some sort in the middle, as in this typical example from the first meeting of Sigurd and Brynhild:

$\begin{array}{cl}\text { Sigurd } & \begin{array}{l}\text { 'I drink, all daring: } \\ \text { doom or glory; } \\ \text { drink of splendour } \\ \text { dear the bearer!' }\end{array} \\ \text { Brynhild } & \text { 'Dear the drinker! } \\ & \begin{array}{l}\text { Doom and glory } \\ \text { both me bodeth, } \\ \text { thou bright and fair!' }\end{array}\end{array}$

(Völ VI.13)

The break in the middle here, as often in the many dialogue sequences, accompanies a change in speaker. Sometimes the speaker is identified in the poem itself, but like his Norse sources Tolkien frequently, as here, only gives a marginal note to indicate who a speech belongs to. The parallelism of the two halves of this stanza is especially heightened, with its chiastic endearments and Sigurd's words echoed and darkly 
altered by Brynhild. Not every stanza is so tightly mirrored as this, but most have some sort of comparable shift or break at the midpoint.

This stanzaic structure has great effects on the presentation of the narrative, with each stanza presenting a scene or thought before, often abruptly, moving onto a new moment in the next. ${ }^{30}$ This pointillistic presentation contrasts with the Old English style, where transitions are frequently gradual, and often smoothed over by the use of enjambment, which binds distinct elements into the same metrical line. These structural changes create a very different overall poetic effect, well described by Tolkien:

In Old English breadth, fullness, reflection, elegiac effect, were aimed at. Old Norse poetry aims at seizing the situation, striking a blow that will be remembered, illuminating a moment with a flash of lightning - and tends to concision, weighty packing of the language in sense and form ... (Tolkien 2009, 7)

These words stand fairly well as a comparison of the Fall of Arthur and the Völsungakviða, though the former never reached its ending, where its elegiac effect presumably would have reached its full development.

In its largest structure, the Völsungakviða is, like the Fall of Arthur, divided into a series of sections (Christopher Tolkien avoids the term 'canto' for this

30 It is interesting to note that a very similar set of narrative techniques has been, quite independently, developed by writers of comic books and graphic novels. 
work). However, these divisions are not so regular in length as in the Arthurian poem, and have a very different narrative effect. In the Fall of Arthur the narrative structure is complex and interwoven, moving from one corner of the world to another as it describes a single set of widely spread but interconnected events, overtly linked by weather and news. The Norse poem is, by contrast, linear, following a single narrative thread from beginning to bitter end. Each section of the Lay of the Völsungs relates a more or less self-contained episode, much as its Eddaic source is made up of a number of discrete poems strung together-although Tolkien's sections are much more coherently linked and tightly worked as parts of a single poem when compared to the rather heterogeneous and eclectic Norse collection.

The transitions between sections are often just as abrupt as those between stanzas, but Tolkien is careful to establish poetic and thematic links which bind the whole work together every bit as tightly as the Fall of Arthur's more obviously elaborate apparatus. The joins are particularly fine across sections V, 'Fáfnir', VI, 'Brynhild', and VII, 'Gudrún', where the story moves from the mythological world of the Völsungs to the legendary realm of the Nibelung family. The introduction of this family begins at the end of section $\mathrm{V}$, when a prophetic finch introduces a formula that will be repeatedly echoed:

Green run the roads

to Gjúki's land

(Völ V.51.5-6) 
In the last stanza of section VI, when Sigurd leaves Brynhild to win back his kingdom, the phrase, with its distinctively craggy type $\mathrm{E}$ line 'green run the roads', is nearly repeated:

Green ran the roads that Grani strode

(Völ VI.23.3-4)

We then jump suddenly, at the start of section VII, to the house of Gjúki the Nibelung, and the troubled dreams of his daughter Gudrún. Gudrún's mother comforts her, telling her to think not on dreams but to look around her, for:

Green lie the lands round Gjúki's house (Völ VII.5.7-8)

In the very next stanza, Sigurd rides up the green roads to his fateful encounter with the Nibelungs.

The linking effects continue later in stanzas 16 through 18 of the same section, when Sigurd sings of his exploits against the dragon Fáfnir and his finding of Brynhild. Many of the lines in Sigurd's song are exact repetitions of those first used to tell the story in section V (the waste lay withered, dark hung the doors), and many more are close variations (and the dread timbers/on deep timbers, from mist rising/from mist uprose). Only two of the 18 lines of Sigurd's song do not have a close correspondent in one of the earlier stanzas, and both are simple narrative connectives to tie the surrounding formulae together (The hoard was plundered and Brynhild wakened). In this and other 
ways, Tolkien links his nine sections, with their varied narrative subjects, together into a single work of art.

As a last comment on Tolkien's style, it is notable that Tolkien avoids certain features common in much of Norse poetry. Alongside the traditional Eddaic poetry, there is a great deal of Norse courtly verse, generally known as Skaldic verse. Among the many distinctive features of this type of poetry is the very extensive use of kennings: compact, often conventional metaphors or poetic analogies. Many of these appear in Eddaic poetry as well, including sources Tolkien used for the Lay of the Völsungs: for instance, Tolkien's sources use the phrase 'harmer of wood' (lindar váði, Fm 43.4) to refer to the fires around the sleeping Brynhild. Tolkien seems to have studiously avoided this kind of allusive reference, preferring the more understated (and in some ways harder-hitting) style generally more characteristic of the Eddaic poems he loved best.

\section{GUĐRÚNARKVIĐA EN NÝJA}

The other long poem in The Legend of Sigurd and Gudrún, the 'Guðrúnarkviða en nýja eða Dráp Niflunga' ('The New Lay of Gudrún or the Slaying of the Nibelungs'), follows directly on from the narrative of the Völsungakviða, which left the Nibelung court rocked by the disastrous queens' quarrel and the deaths of Sigurd and Brynhild. This second poem, deriving especially from the Norse poems Atlakviða and Atlamál, relates the forced remarriage of Sigurd's 
widow Gudrún to Atli (Attila the Hun), the feud that grows between the Huns and Nibelungs over the dragon hoard won by Sigurd, and the horrifying revenge Gudrún takes on her husband for killing her brothers.

As in narrative, the metre of this poem follows on from the Völsungakviða. The range of patterns is very similar, though there are a few interesting points of divergence in the frequencies with which different types are used: ${ }^{31}$
A $\quad / \mathrm{x} / \mathrm{x} \quad$ GIFTS gave GUNnar (Gud 46.1)
$44.9 \%$
B $\mathrm{x} / \mathrm{x} /$ thy PRICE is PAID (Gud 92.5)
$31.9 \%$
C $\quad \mathrm{x} / / \mathrm{x}$ her LORD LOVED her (Gud 32.5)
$15.7 \%$
Da $\quad / / \mathrm{x} \quad$ STEEP, STONEBUILDed (Gud 71.1)
$1.5 \%$
Db $/ / \mathrm{x} \backslash \quad$ BOARS BLEEDing TUSKED (Gud 110.3)
$1.1 \%$
$\mathrm{E} / \backslash \mathrm{x} /$
WILD GREW the WORDS (Gud 144.7)
$4.9 \%$

Perhaps the most striking fact about this poem is that it contains many fewer type $C$ verses and more of type A when compared with the Fall of Arthur and the Völsungakviða. Quite why Tolkien should have moved away from this rhythmic type is not entirely obvious (the Völsungakviða had quite closely approximated the Norse frequency of the type, $22.4 \%$, whereas this represents a notable reduction), but it may reflect a longer term trend in Tolkien's alliterative versecraft. In

31 These figures are based on a sample consisting of stanzas 1-78 and $156-166$, amounting to 716 verses. 
the staves of the Rohirrim in The Lord of the Rings, type C is used $19.2 \%$ of the time: higher than in the Lay of Gudrún, but closer to it than to any other of Tolkien's poems I have scanned. In both the Guðrúnarkviða and the verses in The Lord of the Rings, type C's loss is type A's gain: this latter type constitutes $44.9 \%$ of the verses in both sets of poems. Interestingly, in the very late For W.H.A., the percentage of type $\mathrm{C}$ is even lower, just $12.5 \%$, though with type $\mathrm{B}$, rather than $\mathrm{A}$, showing a marked increase (see Phelpstead (2013, 53)).

The Lay of Gudrún also has a more even spread across the minor verse types $\mathrm{Da}, \mathrm{Db}$, and $\mathrm{E}$, which are in total slightly more frequent than in the other poems compared-though not yet so frequent as in the Rohirrim verses, where type E forms a full $11.5 \%$ of the total. Taken with the move away from type $\mathrm{C}$ and the increased use of type $A$, the scansion of this poem may-and I must stress the 'may'-be the latest of these three poems, all written during a period of deep experimentation with the form, and therefore the closest to Tolkien's mature verse in The Lord of the Rings.

\section{MÁLAHÁTTR AND SYLLABLE COUNTS}

The Lay of Gudrún draws on a number of Eddaic poems, but the two most important are the Atlakviða and the Atlamál. Neither of these poems is entirely in the standard fornyrdislag metre Tolkien emulated, nor in the ljóðaháttr metre of so many other Eddaic poems. 
The Atlamál, usually regarded as a fairly late poem plausibly composed in Greenland, instead uses a verse form called málaháttr, the 'style of speech', which is easiest to describe as a heavier type of fornyrðislag incorporating expanded types and anacrusis into its core rhythms. The much earlier Atlakviða, often held to be one of the oldest Eddaic poems, is harder to pin down metrically, seeming to encompass the full range of types allowed by both fornyrðislag (down to extrashort three-syllable verses) and málaháttr.

There is little trace of the heavier metres of its sources in the Guðrúnarkviða. The average number of syllables per line is 4.34 , which, while higher than the Völsungakviða's 4.29, is considerably lower than either the Fall of Arthur (4.48) or the verses from The Lord of the Rings (4.64). The only possible málaháttrlike feature of the poem is its freer use of anacrusis: fully half of all verses with anacrusis have single alliteration. But this can, like the decrease in the use of type $C$, be seen instead as a part of Tolkien's general development as an alliterative writer, since the poetry from The Lord of the Rings is also very flexible in allowing anacrusis with single alliteration (the respective rates of double alliteration are $49.1 \%$ and $50 \%$, compared to $75 \%$ for the other works reviewed here). Moreover, Tolkien remained fairly consistent about restricting anacrusis to the first half-line in a pair, while málaháttr freely allowed it in either verse. Tolkien's use of anacrusis in the Guðrúnarkviða seems significant, but only in the context of his own development as an alliterative writer, not as a use of ancient metrical features. 


\section{STYLE AND STRUCTURE}

The Lay of Gudrún resembles the Völsungakviða in many ways both large and small, although it is not divided into sections and its 166 stanzas run continuously with only an occasional star to mark a transition. In addition to the sorts of things that have already been mentioned, there is a striking use of ornamental rhyme at the end of the Lay. Tolkien heightens the pain of Gudrún's final words through rhyme on the even numbered lines, further enhanced by the grammatical echoes of the metrically prominent pronouns 'me' and 'thee':

Sigurd, Sigurd, on swift Grani

lay saddle and bridle and seek for me!

the light I would leave to look for thee, from hell thou wouldst ride and haste to me!'

(Gud 163.5-8, 164.5-8)

\section{TOlKIEN's Alliterative VerSE}

The three poems reviewed here represent perhaps Tolkien's most successful experiments in long narrative alliterative verse. One need not argue with Tom Shippey's claim that the verses in The Lord of the Rings, 
short and occasional rather than extended tales, are his best in order to recognize these earlier works as a very significant achievement. Metrically, they show how familiar Tolkien was with medieval alliterative verse, and how he adjusted it as needed to fit the language he was working in. There is much in common across all these poems, showing a real style of Tolkienian alliterative verse with its own conventions regarding anacrusis and preference for certain rhythmic types (especially, in comparison to the ancient poems, types $\mathrm{Db}$ and $\mathrm{E}$ ).

Tolkien introduced enough variants to his alliterative style to suit each poem he worked on: stanzaic structures and fewer syllables for the Norse poems, as well as an occasional three-syllable verse; fuller lines and Hakenstil for Arthur. That the common core of Tolkienian alliterative verse remained basically the same despite these variations is shown by the use of identical or very similar formulaic lines spanning multiple poems. The howling of wolves, typically in the past progressive, is found in the same half-line in the Lay of Gudrún and the Fall of Arthur, and with minimal variations in the Lay of the Völsungs and elsewhere in the Guðrúnarkviða:

wolves were howling (Arth I.78a and IV.1a;

Gud 149.5)

wolves came howling (Völ II.37.7)

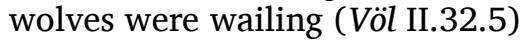

wolves were yammering (Gud 154.6)

hounds were howling (Gud 174.7) 
Other close or identical sets of formulae can be found linking any two of the three poems reviewed here:

steeds went striding, / stonefire glinted

(Gud 61.1-2)

steeds were striding, / stonefire glinting

(Völ VIII.18.5-6)

wild blow the winds

(Arth I.160a; cf. II.94a)

wild blew the winds

(Völ III.1.5 and IV.15.5; cf. II.20.5)

through hoar forest

(Gud 39.4; cf. 61.5 and 63.1)

and hoar forest

(Arth I.102b)

This use of artfully varied formulae lends Tolkien's verse a unified character and reinforces the sense that despite their differences, these three poems are indeed closely associated as part of the same 'tradition'.

This metrical and formulaic commonality is not at odds the different styles of the poems, which shines through even when virtually identical words are used, as in the vivid battle scenes of the Fall of Arthur and the Lay of Gudrún:

There was clang of iron and clash of axes;

sparked and splintered spears and helmets;

the smiths of battle on smitten anvils

there dinned and hammered deadly forging

wrath and ruin.

(Arth IV.181-185a) 


\begin{abstract}
At the dark doorways
they dinned and hammered;

there was clang of swords

and crash of axes.

The smiths of battle

smote the anvils;

sparked and splintered

spears and helmets.

(Gud 100)
\end{abstract}

The scene in the Guðrúnarkviða remains steadfastly paratactic and pointillistic, with strong syntactic breaks between each pair of half-lines giving a fragmented picture of the chaos of battle. The quoted passage in Arthur starts out much the same, but through the smallest of changes ('they' for 'there', 'on smitten' for 'smote the') link together the last five half-lines into a flowing sequence. The final two verses, 'deadly forging / wrath and ruin', give the whole scene a sense of grim perspective. By small rearrangements and shifts, Tolkien makes one passage reflect the 'fullness' of Old English, and the other echo the 'force' of Norse, to follow Tolkien's contrasting descriptions of the two traditions quoted above.

Fullness and force are good words with which to end this review. The details of rhythmic types and metrical tricks are rather technical-dry and dusty, some might say-but they are what give alliterative verse its poetic qualities. The alternation of types, the rolling $\mathrm{A}$ and $\mathrm{B}$, the clashes of $\mathrm{C}$ and $\mathrm{D}$, E's ponderous fall and rise-these things form the texture of the poems, varied and shifting, but held together by the constant threads of alliteration and formula. This balance of flexibility and consistency is at least part of what makes alliterative verse so eminently suitable for 
the range of styles and effects Tolkien aims for. One does not have to understand metrical niceties to feel the hammer-strokes of the Norse poetry, or be moved by the descriptions in the Fall of Arthur, but by looking at the lines and strokes of the verses we can see something of the poetry itself, admiring the artist's skill and hearing more beauty in the whole.

\section{References}

Árnason, Kristján. 1991. The Rhythms of Dróttkvcett and Other Old Icelandic Metres. Reykjavík: Institute of Linguistics, University of Iceland.

Bliss, Alan J. 1962a. The Metre of Beowulf. Oxford: Blackwell.

Basil Blackwell.

Bredehoft, Thomas A. 2005. Early English Metre. Toronto: University of Toronto Press.

Cable, Thomas M. 1974. The Meter and Melody of Beowulf. Urbana: University of Illinois Press.

University of Pennsylvania Press.

Dobbie, Elliot Van Kirk, ed. 1942. The Anglo-Saxon Minor Poems. The Anglo-Saxon Poetic Records VI. New York: Columbia University Press.

Dronke, Ursula. 1969-2011. The Poetic Edda. Vol. I: Heroic Poems. Vol. II: Mythological Poems I. Vol. III: Mythological Poems II. Oxford: Clarendon Press. 
Fulk, R. D. 2004. "Old English Poetry and the Alliterative Revival: On Geoffrey Russom's 'the Evolution of Middle English Alliterative Meter'." In Studies in the History of the English Language II, edited by Anne Curzan and Kimberly Emmons, 305-12. Berlin: Mouton de Gruyter.

Fulk, R. D., Robert E. Bjork, and John D. Niles, eds. 2009. Klaeber's Beowulf and the Fight at Finnsburg. 4th ed. Toronto: University of Toronto Press.

Hartman, Megan E. 2014. "The Limits of Conservative Composition in Old English Poetry." In The Dating of Beowulf: A Reassessment, edited by Leonard Neidorf, 79-96. Cambridge: D.S. Brewer.

Heusler, Andreas. 1925. Deutsche Versgeschichte: Mit Einschluss Des Altenglischen Und Altnordischen Stabreimverses. Berlin: Walter de Gruyter \& Co.

Neckel, Gustav, ed. 1914. Edda: Die Lieder Des Codex Regius Nebst Verwandten Denkmälern. Heidelberg: Carl Winter.

Neidorf, Leonard, and Rafael J. Pascual. 2014. "The Language of Beowulf and the Conditioning of Kaluza's Law." Neophilologus 98 (4): 657-73.

Phelpstead, Carl. 2013. “For W. H. a.': Tolkien's Poem in Praise of Auden." In Tolkien's Poetry, edited by Julian Eilmann and Allan Turner, 45-58. Zurich: Walking Tree Publishers.

Pope, John C., and R. D. Fulk, eds. 2001. Eight Old English Poems. 3rd ed. London: W. W. Norton \& Company.

Russom, Geoffrey. 1987. Old English Meter and Linguistic Theory. Cambridge: Cambridge University Press.

-1998. Beowulf and Old Germanic Metre. Cambridge Studies in Anglo-Saxon England 23. Cambridge: Cambridge University Press.

- 2000. "Tolkien's Versecraft in the Hobbit and the Lord of 
the Rings." In J.R.R. Tolkien and His Literary Resonances, edited by George Clark and Daniel Timmons, 53-69. London: Greenwood Press.

- 2004. "The Evolution of Middle English Alliterative Meter." In Studies in the History of the English Language II, edited by Anne Curzan and Kimberly Emmons, 279-304. Berlin: Mouton de Gruyter.

Shippey, Tom. 2010. "Untitled Review of the Legend of Sigurd and Gudrún." Tolkien Studies 7: 291-324.

—. 2013. “Tolkien's Development as a Writer of Alliterative Verse." In Tolkien's Poetry, edited by Julian Eilmann and Allan Turner, 11-28. Zurich: Walking Tree Publishers.

Sievers, Eduard. 1885. "Zur Rhythmik Des Germanischen Alliterationverses I." Beitrāge Zur Geschichte Der Deutschen Sprache Und Literatur 10: 209-314.

-1893. Altgermanische Metrik. Halle: Max Niemeyer.

Suzuki, Seiichi. 2014. The Meters of Old Norse Eddic Poetry: Common Germanic Inheritance and North Germanic Innovation. Ergänzungsbände Zum Reallexikon Der Germanischen Altertumskunde 86. Berlin: De Gruyter.

Terasawa, Jun. 2011. Old English Metre: An Introduction. Toronto: University of Toronto Press.

Tolkien, J.R.R. 1929. "Ancrene Wisse and Hali Meiðhad." Essays and Studies 14: 104-26.

- 1983. "On Translating Beowulf." In The Monsters and the Critics: And Other Essays, edited by Christopher Tolkien, 4971. London: Allen \& Unwin.

2009. The Legend of Sigurd and
Christopher Tolkien. London: HarperCollins.

- 2013. The Fall of Arthur. Edited by Christopher Tolkien. London: HarperCollins. 
Yakovlev, Nicolay. 2008. "The Development of Alliterative Metre from Old to Middle English." PhD thesis, University of Oxford. 